\title{
INFLUENCE OF THE RADISH HOMOGENATE ON THE FUNCTIONAL AND TECHNOLOGICAL PROPERTIES OF MODEL MINCED MEAT
}

\section{ВЛИЯНИЕ ГОМОГЕНАТА РЕДЬКИ НА ФУНКЦИОНАЛЬНО- ТЕХНОЛОГИЧЕСКИЕ СВОЙСТВА МОДЕЛЬНЫХ ФАРШЕЙ}

Bitueva E.B., Biltrikova T.V.

East Siberia State University of Technology and Management, Ulan-Ude, Russia

Ключевые слова: мясные системы, водосвязывающая способность, влагоудерживающая способность, гомогенат редьки черной, бинарные фариевые модели.

\begin{abstract}
Аннотация
Установлено, что включение гомогената редьки черной в модельные фарии из разных видов мяса (говядина, свинина, курятина) способствует повышению степени гидробильности системы. В опьтных образиах с увеличением содержания гомогената редьки $(10,20,30,40,50) \%$ к массе мяса повышается водосвязывающая способность. Так в говяжьем фарше она увеличилась от 68 (контроль) до $80 \%$ (50\% гомогената редьки черной), в свином - от 55 до $73 \%$ и курином - от 72 до $82 \%$ соответственно. Повышение водосвязывающей способности в модельных фаршах обосновано смешением рН от 5,9-6,05 до 6,25-6,43 (в зависимости от вида мяса) и содержанием нейтральных солей в дисперсионной среде гомогената редьки. Также в модельных фаршах установлено повышение и влагоудерживающей способности. Значения варьировали от $10 \%$ (модели с куриным фаршем) до 25\% (свиной фарш) относительно контроля. В модельных фаршах клетчатка и пектиновые вещества редьки прочно связывают воду и после тепловой обработки выполняют функции стабилизатора системы. Установлено, что включение гомогената редьки черной в мясные фаршевые системы из разных видов мяса повышает функиионально-технологические показатели.
\end{abstract}

\section{Введение}

Современные представления о здоровой пище основаны на концепции оптимального питания, которая обосновывает необходимость и обязательность обеспечения организма не только в энергии, эссенциальных макро- и микронутриентах, но и в целом ряде необходимых минорных биологически активных компонентов, в частности хемопревенторов [1]. Для удовлетворения физиологических потребностей организма в минорных компонентах недостаточно ассортимента существующих мясных продуктов. На сегодняшний день является актуальным создание новых видов мясной продукции, употребление которых будет соответствовать принципам здорового питания, с одной стороны, и корректировать недостаток биологически активных веществ - с другой. В этом отношении мясорастительные изделия могут занять достойное место в рационе современного человека. В рецептурах мясных изделий в зависимости от вида растительного сырья достигаются разные цели: обогащение витаминами, минеральными веществами,
Keywords: meat system, water binding capacity, moisture holding capacity, black radish homogenate, binary models of minced meat.

\begin{abstract}
It was established that inclusion of black radish homogenate into model minced meat from different meat types (beef, pork, chicken) facilitates an increase in a degree of system hydrophilicity. In the experimental samples, the water binding capacity increased with an increase in the radish homogenate content at a level of 10, 20, 30, 40, $50 \%$ of meat weight. For example, in minced beef, it increased from $68 \%$ (control) to $80 \%$ (50\% of black radish homogenate), in minced pork from 55 to $73 \%$, in minced chicken from 72 to $82 \%$, respectively. An increase in water binding capacity in model minced meat was due to a pH shift from 5.9-6.05 to 6.256.43 (depending on a meat type) and the content of neutral salts in the dispersion system of the radish homogenate. An increase in moisture holding capacity was also established in model minced meat. The values varied from $10 \%$ (models with minced chicken) to $25 \%$ (minced pork) compared to control. In model minced meat, fibers and pectin substances of the black radish strongly bind water and act as a system stabilizer after thermal treatment. It was found that addition of the black radish homogenate in minced meat systems from different meat types increased the functional and technological indicators.
\end{abstract}

\section{Introduction}

Modern insights of healthy food are based on the concept of optimal nutrition, which substantiates the need for provision of the body not only in energy, the essential macro- and micro-nutrients but also in several necessary minor biologically active components, in particular, chemopreventors [1]. To satisfy the physiological requirements of the body in the minor components, an available assortment of meat products is not sufficient. Nowadays, it is urgent to create new types of meat products, which consumption, on the one hand, will correspond to the principles of healthy nutrition, and, on the other hand, will correct a deficiency of the biologically active substances. In this regard, meat-and-plant products can occupy a highly important place in the modern human diet. The recipes of meat products achieve different goals depending on the type of plant raw material: enrichment with vitamins, minerals and dietary fibers; improvement of the functional and 
пищевыми волокнами; улучшение функциональнотехнологических свойств; снижение калорийности и стоимости мясных продуктов $[2,3,4]$. Так, например, при использовании тыквенного порошка увеличиваются массовая доля прочносвязанной влаги, выход изделий, что связано с полисахаридами растительного ингредиента [4]. Использование композитной смеси из корнеплодов пастернака и бобов нута в комбинированных мясных системах способствует повышению всех функционально-технологических свойств мясных фаршей и стабилизации качества мясной системы. Максимальные значения водосвязывающей и влагоудерживающей способностей достигаются при введении функциональной добавки в количестве 3,0-3,5\% в фарш взамен основного сырья и составляют соответственно 70,6-71,5\% и 64,7-66,1\% [5]. Используются также мука, например льняная, при замене основного сырья на 5, 10 и 20\% наблюдалось увеличение водосвязывающей способности фарша. При использовании замороженного сырья, в опытных образцах по сравнению с контролем она увеличилось на 9 и $17 \%$ при внесении соответственно 10 и $20 \%$ льняной муки [6].

В мясной системе используются не только наземное растительное сырье, но и морские водоросли. Разработаны технологии мясных продуктов с пищевыми добавками на основе морских водорослей. Готовые продукты отличаются высокими функционально-технологическими показателями, и обладают лечебнопрофилактическими свойствами $[7,8]$.

Достаточно часто для коррекции функциональнотехнологических свойств мясной системы используют изолированные пищевые волокна, в частности применение в производстве вареных колбас яблочных, тыквенных, пшеничных, свекловичных, солодовых пищевых волокон, полученных методом ферментативной обработки сырья [9].

Одним из источников биологически активных веществ, в том числе и хемопревенторов, являются овощи семейства крестоцветных, так например, редька черная известна с древних времен как профилактическое и лечебное средство при различных заболеваниях. На сегодняшний день исследования ряда ученых свидетельствуют с позитивных свойствах редьки черной, так при исследовании в опытах in vivo, установлено, что сок редьки черной обладает антиоксидантыми свойствами [10]. Также установлено положительное влияние редьки черной на морфофункциональные характеристики слизистой оболочки кишечника в опытах на экспериментальных животных [11]. В настоящее время спектр ее применения в мясной промышленности достаточно узок.

Включение растительного сырья в мясные системы требует всестороннего изучения сочетаемости, в частности в плане изменения гидрофильных свойств мясной системы. Изменения данных свойств мяса влияют на показатели товарного вида, пищевую ценность, выход продукта. И зависят от многих причин, в частности technological properties; reduction of the calorie content and cost of meat products $[2,3,4]$. For instance, when using pumpkin powder, the mass fraction of strongly bound moisture and product yield increase, which is associated with polysaccharides of the plant ingredient [4]. The use of the composite mixture from parsnip roots and chickpea in the combined meat systems facilitates an increase in all functional and technological properties of minced meat and stabilization of meat system quality. Maximum values of water binding and moisture holding capacities are achieved upon addition of the functional additive in an amount of 3.0-3.5\% into minced meat instead of the main raw material and are equal to $70.6-71.5 \%$ and $64.7-66.1 \%$, respectively [5]. Meal, for example linseed meal, is also used when replacing main raw material at a level of 5, 10 and $20 \%$, which leads to an increase in water binding capacity of minced meat. When using frozen meat raw material, it increased by 9 and $17 \%$ in the experimental samples compared to the control upon addition of 10 and $20 \%$ of linseed meal, respectively [6].

Not only terrestrial plant raw material but also marine algae are used in a meat system. The technologies of meat products with food additives based on marine algae were developed. Finished products are characterized by high functional and technological indicators and have curative and prophylactic properties [7, 8].

Isolated dietary fibers obtained by the method of enzyme processing of raw material and used in cooked sausage production (in particular, apple, pumpkin, wheat, beat, malt dietary fibers) are quite often applied for correction of the functional and technological properties of a meat system [9].

One of the sources of the biologically active substances, including chemopreventors, is vegetables of the family Cruciferaceae; for example, black radish is known since ancient times as a prophylactic and curative agent in various diseases. Today, studies of several scientists suggest the positive properties of black radish. For example, it was established in in vivo experiments that the juice from black radish had the antioxidant properties [10]. It was also found that black radish had a positive effect on the morphofunctional characteristics of the intestinal mucosa in the experiments on animals [11]. At present, a range of its use in the meat industry is rather narrow.

Inclusion of plant raw material in meat systems requires a comprehensive study of compatibility, in particular, in terms of changes of the hydrophilic properties of a meat system. Changes in these meat properties affect the indicators of marketable appearance, nutritional value and product yield and depend on many reasons, in particular, on the condition 
от состояния исходного сырья, термического состояния мяса, влияния условий хранения, технологических процессов и др. $[12,13]$ И, тем не менее, возможно контролировать изменения функционально-технологических свойств мяса путем включения различных ингредиентов, в том числе растительного сырья [14].

Целью работы являлось изучение изменения функционально-технологических свойств при включении гомогената редьки черной в модельные мясные системы.

\section{Материалы и методы}

Для проведения экспериментов использовали стандартные и общепринятые физико-химические методы исследований.

Объекты исследования представляли бинарную модель, состоящую из фарша разных видов мяса (говяжий, свиной и куриный) и редьки. Редьку вводили в гомогенизированном виде в количествах $(10,20,30$, $40,50) \%$ к массе мясного сырья. Исследовали показатели, характеризующие функционально-технологические свойства фаршевых систем: водосвязывающую, влагоудерживающую способности и $\mathrm{pH}$ модельных фаршей.

Водосвязывающую способность (ВСС) определяли методом прессования по Грау-Хамма. Метод основан на выделении воды образцом при легком прессовании, сорбции выделившейся воды фильтровальной бумагой и определении количества отделившейся влаги по размеру площади пятна, оставляемого на фильтровальной бумаге.

Массовую долю связанной влаги в образце вычисляли по формуле:

$$
X=\frac{(A-8,4 \times 5) \times 100}{A}
$$

где $X$ - массовая доля связанной влаги в образце, \% к общей влаге; $A-$ общая масса влаги в навеске, мг; 5 - площадь влажного пятна, мм².

Влагоудерживающую способность (ВУС), определяли по методу, разработанному Р. М. Салаватулиной. Образцы фарша массой (180-200) г закатывали в консервные банки, взвешивали и подвергали тепловой обработке, охлаждали в проточной воде до комнатной температуры и затем в течение (12-18) ч при температуpe (3-6) ${ }^{\circ} \mathrm{C}$. Бюксы с бульоном помещали в сушильный шкаф и при температуре (103-105) ${ }^{\circ} \mathrm{C}$ доводили до постоянной массы. Определяли содержание влаги, выделившейся при тепловой обработке и влагоудерживающую способность фарша по следующей формуле:

$$
B У C=B-(Д \times 8) /(M \times A) \times 100 \%,
$$

где $B-$ содержание влаги в фарше, \%; Д - масса всего отделившегося бульона с жиром, г; в - масса воды в исследуемом бульоне, г; $M$ - масса исследуемого бульона с жиром, г.; $A-$ масса навески фарша, г.

Определение $\mathrm{pH}$ растворов проводили ионометрическим методом. Принцип работы основан на измере- of the initial raw material, meat thermal condition, effects of storage conditions, technological processes and so on $[12,13]$. Nevertheless, it is possible to control changes in the functional and technological meat properties by addition of different ingredients including plant raw material [14].

The aim of the research was to study changes in functional and technological properties when adding the black radish homogenate into the model meat systems.

\section{Materials and methods}

The standard and conventional physico-chemical methods of investigation were used in the experiments. The subjects of the experiments presented a binary model that consisted of minced meat of different types (beef, pork and chicken) and radish. Radish was introduced in a homogenized form in amounts of 10, 20, 30, 40 and $50 \%$ of meat raw material weight. The indicators characterizing functional and technological properties of minced meat systems (the water binding and moisture holding capacities and $\mathrm{pH}$ of model minced meat) were analyzed.

The water binding capacity (WBC) was determined by the filter-paper press method (Grau and Hamm). The method is based on releasing water by a sample under slight pressure, sorption of the released water by filter paper and detection of an amount of separated water by a spot area on filter paper.

The mass fraction of bound moisture in a sample was calculated by an equation:

$$
X=\frac{(A-8,4 \times B) \times 100}{A},
$$

where, $X$ - mass fraction of bound water in a sample, $\%$ of total moisture; $A-$ total mass of moisture in a specimen, $\mathrm{mg} ; B-$ area of the wet spot, $\mathrm{mm}^{2}$;

The moisture binding capacity (MBC) was determined by the method developed by R.M. Salavatulina. Minced meat samples with a weight of 180-200 g were sealed in cans, weighed and subjected to thermal treatment, cooled in flowing water up to a room temperature and then at a temperature of $3-6^{\circ} \mathrm{C}$ for $12-18$ hours. The weighing bottles with broth were put in a drying chamber and were brought to a constant weight at a temperature of $103-105^{\circ} \mathrm{C}$. The content of moisture released upon thermal treatment and the moisture holding capacity of minced meat were determined by the following equation:

$$
W H C=W-(D \times w) /(M \times A) \times 100 \%,
$$

where, $W$ - water content in minced meat, $\% ; D$ - weight of the total separated broth with fat, g; $w$ - weight of water in broth under investigation, g; $M$ - weight of broth with fat under investigation, g; $A-$ weight of minced meat specimen, $g$.

$\mathrm{pH}$ of solutions was measured by the ionometric method. The principle of operation is based on measurement 
нии электродвижущей силы элемента, состоящего из электрода сравнения с известной величиной потенциала и индикаторного электрода, потенциал которого обусловлен концентрацией ионов водорода в испытуемом растворе.

Для подтверждения достоверности полученных экспериментальных данных проводили статистическую обработку по результатам 5-9 параллельных опытов с уровнем достоверной вероятности $\mathrm{p}<0,05$. Использовались программные ресурсы Microsoft Office Excel 2010 и пакет программ Statistic.

\section{Результаты и обсуждение}

Во всех опытных образцах с увеличением содержания гомогената редьки повышалась водосвязывающая способность модельных систем. Притом, что в модельные системы не добавлялась вода. Компоненты исследуемых моделей в измельченном состоянии представляют собой дисперсные системы. Дисперсная фаза в мясных фаршах включает белковые и жировые частицы, в гомогенате редьки - в основном, частицы полисахаридов. Дисперсионная среда обоих компонентов представлена растворами электролитов с включением различных низкомолекулярных органических и неорганических веществ. В отличие от мясной системы, дисперсионная среда гомогената включает в основном растворимые продукты деструкции полисахаридов (моно-, дисахара, растворимые пектины), фенольные и индольные соединения. При смешивании измельченного мяса с гомогенатом редьки, влага последнего адсорбируется фаршем, так как влажность образцов разных видов мяса находилась в пределах (7075)\%, а влажность растительного ингредиента - 86\%.

Результаты исследований водосвязывающей способности опытных образцов представлены на рисунке 1.

Экспериментальные данные, представленные на рисунке 1, свидетельствуют о том, что с увеличением количества гомогената до $50 \%$ к массе мясного сырья водосвязывающая способность в опытных образцах повышается в среднем на $17 \%$ относительно контрольных образцов, включавших только измельченное мясо. Так в говяжьем фарше она увеличилось от 68 (контроль) и до $80 \%$ при $50 \%$ включении гомогената, в свином - от 53 до $73 \%$ и курином — от 72 до $82 \%$.

Математическая и графическая обработка данных свидетельствует о высокой точности теоретического описания и практических определений исследуемых величин.

Известно, что на значения ВСС оказывает влияние $\mathrm{pH}$. Исходное значение $\mathrm{pH}$ фаршей варьировало от 5,9 до 6,05 в зависимости от вида мяса, $\mathrm{pH}$ гомогената редьки - 6,6. При увеличении количества вносимого гомогената в фарши наблюдали сдвиг $\mathrm{pH}$ до 6,206,43 (в зависимости от вида мяса) при 50 \% включении гомогената (рис. 2).

Безусловно, повышение ВСС модельных систем при включении гомогената редьки связано со свойствами of the electromotive force of an element that consists of a reference electrode with known value of potential and an indicator electrode, which potential is conditioned by a concentration of the hydrogen ions in a test solution.

To confirm the reliability of the obtained experimental data, statistical processing according to the results of 5-9 parallel experiments with a probability $\mathrm{p}<0.05$ was carried out. Microsoft Office Excel 2010 and software package Statistic were used.

\section{Results and discussion}

In all experimental samples, the water binding capacity of the model systems increased with an increase in the content of the radish homogenate. With that, water was not added into the model systems. The components of the studied models in the minced condition are disperse systems. The disperse phase in meat products includes protein and fat particles, in the radish homogenate mainly polysaccharide particles. The dispersion medium of both components is presented by electrolyte solutions with inclusion of different low molecular weight organic and inorganic substances. In contrast to the meat system, the dispersion medium of the homogenate includes mainly soluble products of polysaccharide destruction (monosaccharides and disaccharides, dissolved pectines), phenolic and indolic compounds. When mixing minced meat with the radish homogenate, moisture of the latter is absorbed by minced meat as moisture of the samples from different meat types was in a range of $70-75 \%$, and moisture of the plant component was $86 \%$.

The results of the investigation of the water binding capacity of the experimental samples are presented in Fig. 1.

The experimental data presented in Fig. 1 suggest that with an increase in an amount of the homogenate up to $50 \%$ of the meat raw material weight, the water binding capacity in the experimental samples increased on average by $17 \%$ compared to the control samples, which included only minced meat. For example, in minced beef it increased from $68 \%$ (control) to $80 \%$ at $50 \%$ inclusion of homogenate, in minced pork from $53 \%$ to $73 \%$ and in minced chicken from $72 \%$ to $82 \%$.

Mathematical and graphical processing of the data demonstrates high precision of the theoretical description and practical measurements of the values under investigation.

It is known that $\mathrm{pH}$ affects the $\mathrm{WBC}$ values. The initial $\mathrm{pH}$ value of minced meat varied from 5.9 to 6.05 depending on the meat type, $\mathrm{pH}$ of the radish homogenate was 6.6. When increasing an amount of the added homogenate into minced meat a shift in $\mathrm{pH}$ up to 6.20-6.43 (depending on a meat type) at $50 \%$ inclusion of the homogenate was observed (Fig. 2).

Undoubtedly, an increase in WBC of the model systems upon addition of the radish homogenate is associated with meat protein properties. For example, when $\mathrm{pH}$ changes by on average 0.38 units from the initial value, an effective charge of the protein molecules increases; it will be negative due to inhibition of dissociation of the main groups. 


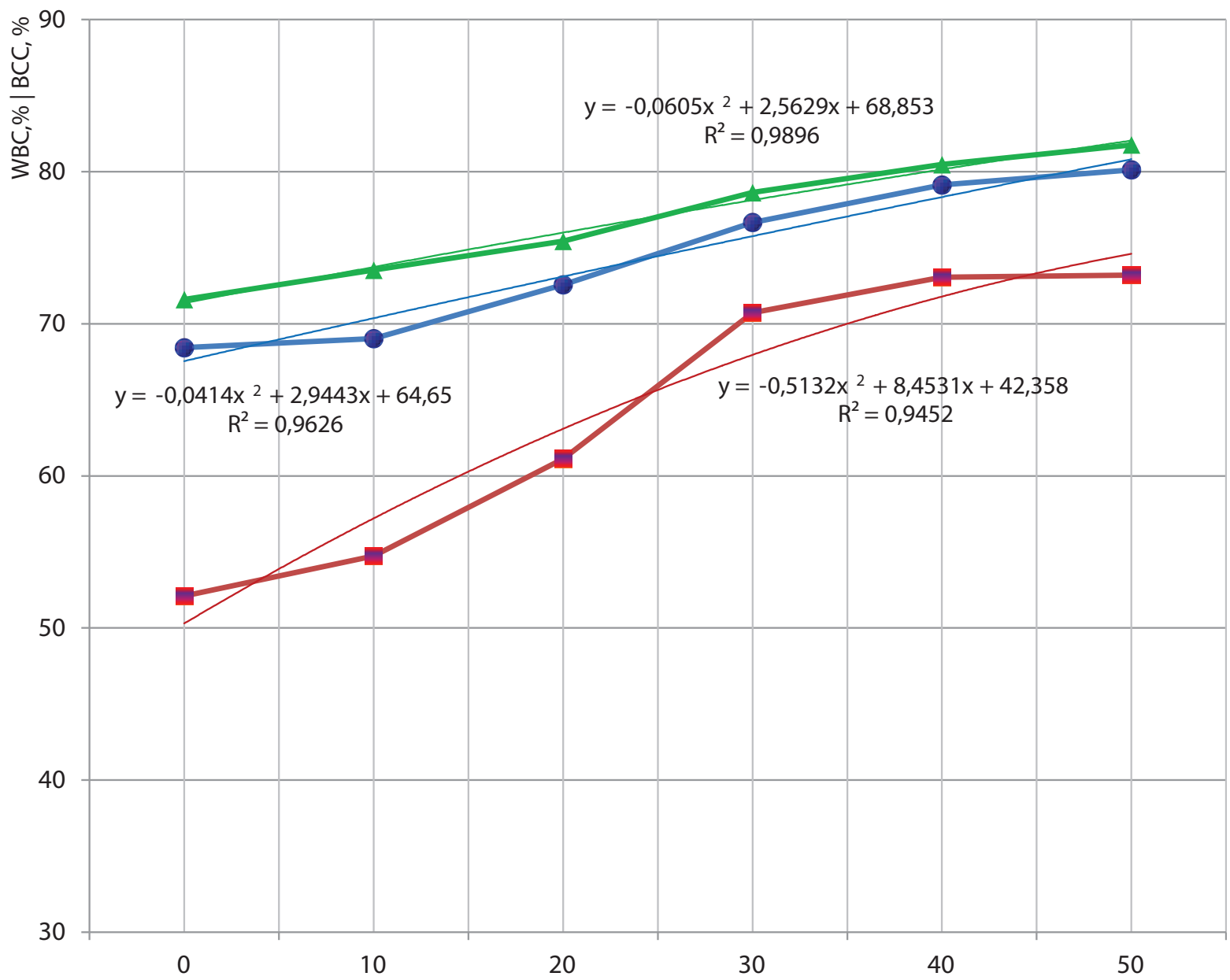

Content of homogenate, \% of meat raw material | Содержание гомогената к массе мясного сырья, \% - beef|говяжий $\rightarrow$ pork|свиной $\rightarrow$ chicken | куриный

Figure 1. Changes in the water binding capacity of the model minced meat Рис. 1. Изменение водосвязывающей способности модельных фаршей

белков мяса. Так, при сдвиге рН в среднем на 0,38 единиц от исходного значения, увеличивается эффективный заряд белковой молекулы, он будет отрицательным в результате подавления диссоциации основных групп. Кроме этого, сама влага гомогената представлена клеточным соком редьки, в котором содержится около (60-80)\% минеральных веществ от общего их количества. И в основном, это соли одновалентных металлов (калия, натрия и др.), в присутствии которых также меняется эффективный заряд молекулы белка. В результате увеличивается гидратация, растворимость белков, повышается осмотическое давление системы и мясной фарш адсорбирует влагу гомогената.

Таким образом, совокупность данных факторов определяет увеличение водосвязывающей способности фаршевых моделей. Однако дальнейшее увеличение содержание растительного ингредиента не способствовало стабилизации системы фаршевых моделей. Фарш не обладал пластичностью, монолитностью и присутствовала свободная влага.

Полученные данные коррелируются с работами ряда авторов, так например, при введении тыквенного концентрата в мясные фарши водосвязывающая

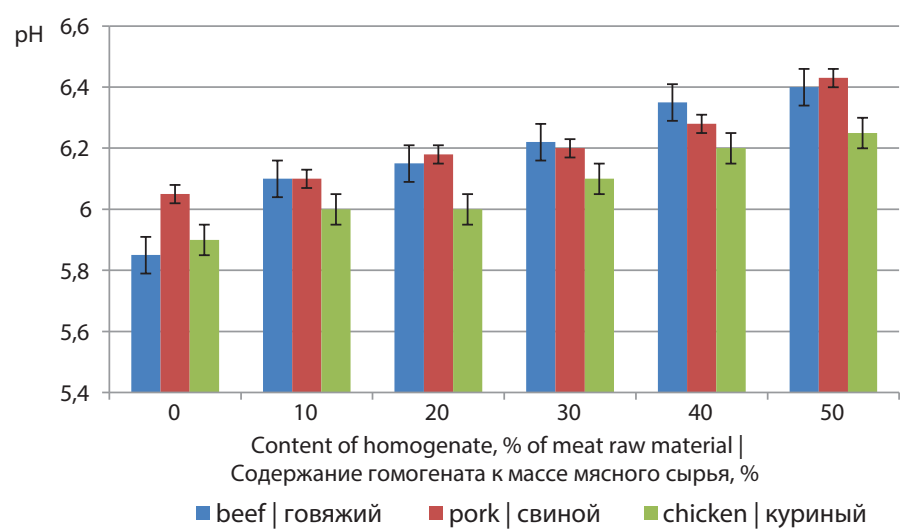

Figure 2. Changes in the $\mathrm{pH}$ value of the model minced meat Рис. 2. Изменение величины рН модельных фаршей

Moreover, homogenate moisture is presented by the radish cell juice, which contains about $60-80 \%$ of minerals of their total amount. Mainly, these are the salts of the monovalent metals (potassium, sodium and others), in which presence an effective charge of the protein molecule also changes. As a result, hydration, protein solubility and osmotic pressure of the system increase and minced meat absorbs homogenate moisture.

Therefore, a complex of these factors determines an increase in the water binding capacity of minced meat models. However, the following increase in the content of 
способность в среднем увеличивается на $10 \%$ относительного контроля [3]. При внесении сушеных овощей, таких как лук, лук-порей, сельдерей в модельные мясные системы было установлено повышение водосвязывающей способности и выхода продукта [15]. Наилучшие показатели были получены при внесении порошка корнеплода сельдерея.

Водосвязывающая способность характеризует свойства сырого фарша. На практике имеет значение свойства системы после тепловой обработки. При нагревании, как известно, происходит денатурация белков, характеризующаяся перегруппировкой водородных связей и дезориентацией полипептидных цепочек [12]. В результате происходит уменьшение гидрофильных и увеличение гидрофобных свойств белковых молекул, сопровождающееся уменьшением степени гидратации и снижением стабилизирующего действия гидратационных слоев вблизи полярных группировок. Белок теряет способность удерживать влагу.

При исследовании опытных моделей фаршей установлено, что после тепловой обработки значения влагоудерживающей способности возрастают относительно контрольных образцов. Так, в модельном курином фарше значение увеличилось на $10 \%$, в говяжьем - на $13 \%$, в свином - на $25 \%$ относительно контроля (рис. 3 ).

Известно, что механизм формирования влагоудерживающей способности связан с образованием гидроколлоидов типа гелей. Денатурированные белки могут оставаться в состоянии гелей только в присутствии стабилизирующего фактора, в исследуемых образцах таковым может быть гомогенат редьки. Данное пред- the plant ingredient did not facilitate stabilization of the minced meat models. Minced meat did not have plasticity and monolithic structure, and contained free moisture.

The obtained data correlate with the works of several authors. For example, addition of the pumpkin concentrate in minced meat resulted in an increase in the water binding capacity on average by $10 \%$ compared to control [3]. When adding dried vegetables such as onion, leek and celery into model minced meat systems, an increase in water binding capacity and product yield was established [15]. The best indicators were obtained when adding powdered celery roots.

Water binding capacity characterizes the properties of raw minced meat. In practice, the properties of the system after thermal treatment are important. It is well known that during heating protein denaturation occurs, which is characterized by rearrangement of the hydrogen bonds and disorientation of the polypeptide chains [12]. As a result, a decrease in the hydrophilic and an increase in the hydrophobic properties of the protein molecules occur, which is accompanied by a decrease in the hydration degree and the stabilizing action of the hydration layers near the polar groups. Protein loses the ability to retain moisture.

When studying the experimental minced meat models, it was established that after thermal treatment, the values of the moisture holding capacity increased compared to the control samples. For example, in the model minced chicken, the value increased by $10 \%$, in minced beef by $13 \%$ and in minced pork by $25 \%$ compared to control (Fig. 3).

It is known that the mechanism of moisture holding capacity formation is associated with development of hydrocolloids of the gel type. Denaturated proteins can stay

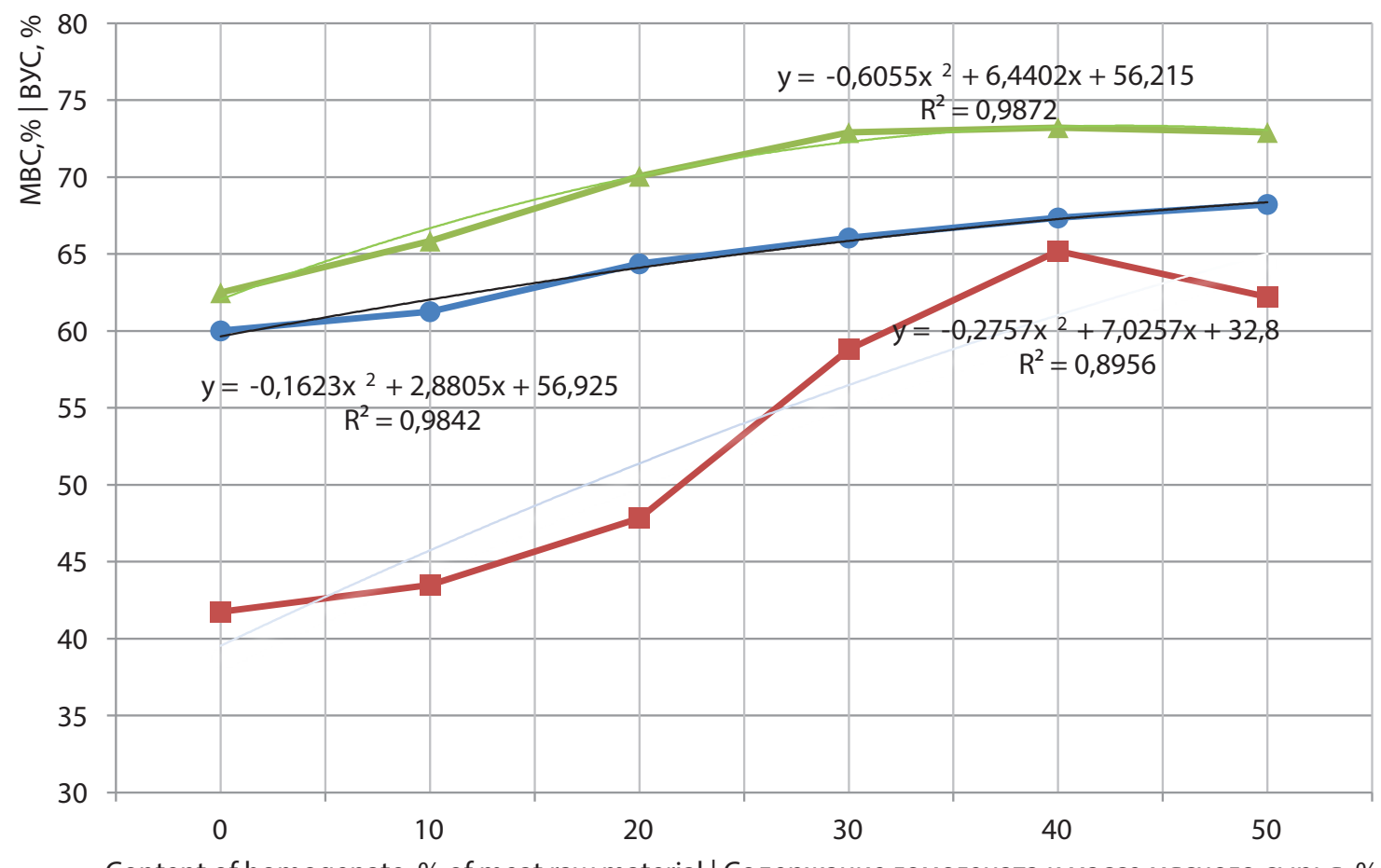

Content of homogenate, \% of meat raw material | Содержание гомогената к массе мясного сырья, \%

Figure 3. Changes in the moisture holding capacity in the model minced meat

Рис. 3. Изменение влагоудерживающей способности модельных фаршей 
положение основано на том, что при тепловой обработке до $60 \%$ протопектина переходит в пектины, которые лучше связывают воду, и также как клетчатка прочно ее удерживают [16]. Еще одним фактором может быть и то, что функциональные группы белков мяса способны взаимодействовать с изотиоцианатами, фенольными и индольными соединениями гомогената редьки. В результате чего создается пространственная гибкая матрица, удерживающая значительную часть воды с растворенными в ней веществами. Поэтому в опытных модельных фаршах с включением гомогената редьки влагоудерживающая способность увеличивается с повышением доли последнего.

Наиболее близкими к исследуемой тематике, является работа, связанная с изучением поведения редиса (radish red) в мясной системе. Так, использовали введение $0,10,20,30,40,50 \%$ редиса в гамбургеры из говядины. Установлено, что высокой водосвязывающей способностью обладали образцы с включением $50 \%$ редиса [17].

Хотелось бы отметить, что с точки зрения гидрофильности модельных фаршевых систем и содержания хемопревенторов предпочтительнее включение $50 \%$ растительного ингредиента в фарши. Однако гомогенат редьки обладает специфическими вкусовыми и ароматическими свойствами не характерными для мясной системы и эту особенность растительного ингредиента необходимо учитывать при дальнейших исследованиях.

\section{Выводы}

В результате, проведенных исследований установлено, что:

- с точки зрения функционально-технологических свойств введение гомогената редьки черной в мясные системы целесообразно;

- водосвязывающая способность модельных систем увеличивается в среднем на $17 \%$ при $50 \%$ включении гомогената к массе мясного сырья;

- в модельных фаршах гомогенат редьки стабилизирует мясные системы после тепловой обработки, влагоудерживающая способность модельных фаршей увеличивается на 10-25\% в зависимости от вида мяса по сравнению с контрольными образцами;

- учитывая химический состав редьки черной при введении ее в мясные системы необходимо проведение исследований органолептических показателей, в частности вкуса и аромата.

БИБЛИОГРАФИЧЕСКИЙ СПИСОК 1. Тутельян В.А. О нормах физиологических потребностей В энергии и пищевых веществах Аля разАичных групп насемения Российской Федерации // Вопросы питания, 2009. № 1. - С. 4-15.

2. Аисицын А.Б. Основные тенденции фундаментальных исследований ВНИИМПа // Мясная индустрия, 2010. - № 11. C. 5-9.

3. Weiss J., Gibis M., Schuh V., Salminen H. Advances in ingredient and processing systems for meat and meat products / Meat Science 86 (2010). - P. 196-213. in the gel state only in the presence of a stabilizing factor; in the tested samples this factor can be the radish homogenate. This hypothesis is based on the fact that upon thermal treatment up to $60 \%$ of protopectin is transformed into pectins, which better bind water and, similar to fibers, strongly holds it [16]. Another factor can be the fact that the functional groups of meat proteins can interact with isothiocyanates, phenolic and indolic compounds of the radish homogenate. As a result, a three-dimensional flexible matrix can be formed, which holds a significant part of water with components dissolved in it. Therefore, in the model minced meat with inclusion of the radish homogenate, the moisture holding capacity is increased with an increase in the fraction of the latter.

The most close to the studied subject is the research connected with the study of the red radish behavior in a meat system. The addition of $0,10,20,30,40,50 \%$ of red radish to hamburgers was used. It was established that the samples with $50 \%$ inclusion of red radish had the high water binding capacity [17].

It is necessary to note that from the point of view of the hydrophilicity of the model minced meat systems and the content of chemopreventors, the addition of $50 \%$ of a plant ingredient into minced meat is preferable. However, the radish homogenate has specific taste and aroma properties, which are not typical for meat systems; and this peculiarity of the plant ingredient is necessary to take into consideration in the future investigations.

\section{Conclusions}

As a result of the performed experiments, it was established that:

- in terms of the functional and technological properties, the addition of the black radish homogenate into meat systems is expedient;

- the water binding capacity of the model systems increased on average by $17 \%$ when adding the homogenate in an amount of $50 \%$ of the meat raw material weight;

- in the model minced meat, the radish homogenate stabilized the meat systems after thermal treatment. The moisture holding capacity of the model minced meat increased by $10-25 \%$ depending on the meat type compared to the control samples;

- taking into consideration the chemical composition of the black radish, it is necessary to study the organoleptic indicators, in particular, taste and aroma, upon its addition into the meat systems.

\section{REFERENCES}

1. Tutelyan V.A. On norms of physiological requirements in energy and nutrients for different groups of the population of the Russian Federation // Voprosy Pitaniya, 2009. - № 1. - P. 4-15. 2. Lisitsyn A.B. The main trends of fundamental research VNIIMP // Meat industry, 2010. - № 11. - P. 5-9.

3. Weiss J., Gibis M., Schuh V., Salminen H. Advances in ingredient and processing systems for meat and meat products / Meat Science 86 (2010). - P. 196-213.

4. Sviridov V.V., Bannikova A.V., Ptichkina N.M. The study of the complex characteristics of chopped meat and fish products, 
4. Свиридов В.В., Банникова А.В., Птичкина Н.М. Изучение комплекса свойств рубленых мясных и рыбных изделий, обогащенных порошком тыквы //Аграрный научный журнал, 2011. - № 7. - C. 61-63.

5. Мельникова Е.С., Курчаева Е.Е., Манжесов В.И., Оробинский В.И., Ясакова Ю.В. Перспективы использования порошка пастернака в получении комбинированных мясных систем высокой функциональности // Вестник Воронежского государственного аграрного университета, 2014. - № 1-2. - С. 190-193. 6. Гуринович Г.В., Рунда О. Аьняная мука и качество мясных рубленых полуфабрикатов // Мясная индустрия, 2013. - № 9. - C. 38-41.

7. Бредихина О.В., Корниенко Н.А., Юзов С.Г. Функциональные продукты на основе животного и растительного сырья // Мясная индустрия, 2012. - № 6. - С. 48-50.

8. Баженова Б.А. Перспективы использования растительных ингредиентов в рецептуре мясопродуктов // Материалы международной научно-практической конференции, посвященной памяти В.М. Горбатова. - Москва, 2014. - № 1. - С. 17-18. 9. Румянцева Г.Н., Комиссарова В.В., Семенова А.А. Использование растительных пищевых волокон в вареных колбасах //Мясная индустрия, 2009. - № 11. - С. 37-39.

10. Lugasi A., Blázovics A., Hagymási K., Kocsis I., Kéry A. Antioxidant effect of squeezed juice from black radish (Raphanus sativus L. var niger) in alimentary hyperlipidaemia in rats / Phytother Res. 2005 Jul; 19(7): 587-91.

11. Sipos P., Hagymási K., Lugasi A., Fehér E., Blázovics A.Effects of black radish root (Raphanus sativus $L$. var niger) on the coIon mucosa in rats fed a fat rich diet / Phytother Res. 2002 Nov; 16(7): 677-9.

12. Соколов А.А. Физико-химические и биохимические основы технологии мясопродуктов. - М.: Пищевая промышленность, 1965. - С. 511.

13. Offer G., Trinick J. On the mechanism of water holding in meat: The swelling and shrinking of myofibrils // Meat Sci. 1983; 8(4):245-81. DOI: 10.1016/0309-1740(83)90013-X.

14. Puolanne E., Halonen M. Theoretical aspects of water-holding in meat // Meat Science.- Vol. 86, Issue 1, September 2010, P. 151-165.

15. Vinauskienè R., Eisinaitè V., Jasutienè I., Leskauskaitè D. Composition and functional properties of meat products with a lyophilised vegetable additive // Food Chemistry and Technology. - Vol. 48. - № 1, 2014. - P. 78-86.

16. Patent WO 2005107500 A1.Vegetable fat replacement in meat products / Tornberg E., Sjöholm I. Published: Nov 17, 2005. 17. Abd-Elhak, Nasra A., Safaa E. Ali, Nahed L. Zaki. Innovative modification of traditional burger // Egypt. J. Agric. Res., 92(3), 2014. - P. 995-1008.

\section{СВЕДЕНИЯ ОБ АВТОРАХ}

Принадлежность к организации

Битуева Эльвира Борисовна - доктор технических наук, профессор, заведующий кафедрой, кафедра «Неорганическая и аналитическая химия», Восточно-Сибирский государственный университет технологии и управления.

670013, Российская Федерация, г. Улан-Удэ, ул. Ключевская, 40в Тел.: 8-914-848-70-02

E-mail: bitueva_elv@mail.ru

Бильтрикова Татьяна Владимировна - аспирант, кафедра «Неорганическая и аналитическая химия», Восточно-Сибирский государственный университет технологии и управления.

670013 , Российская Федерация, г. Улан-Удэ, ул. Ключевская, 40в

Тел.: 8-902-164-85-00

E-mail: biltrikova88@mail.ru

Критерии авторства

Авторы в равных долях имеют отношение к написанию рукописи и одинаково несут ответственность за плагиат.

Конфликт интересов

Авторы заявляют об отсутствии конфликта интересов.

Поступила 19.10.2016 fortified powder pumpkin // Agricultural Research magazine, 2011. - № 7. P. 61-63.

5. Melnikova E.S., Kurchaeva E.E., Manzhesov V.I., Orobinskiy V.I., Yasakova Yu.V. Prospects for the use of parsnip powder to obtain combined meat systems with high functionality // Vestnik of VSAU, 2014. — № 1-2. - P. 190-193.

6. Gurinovich G.V., Runda O. Flax flour and quality of minced meat semi-finished products // Meat industry, 2013. - № 9. P. 38-41.

7. Bredikhina 0.V., Kornienko N.L., Yuzov S.G. Functional foods based on vegetable and animal raw materials // Meat industry, 2012. - № 6. - P. 48-50.

8. Bazhenova B.A. Prospects for the use of herbal ingredients in the formulation of meat products // Proceedings of the international scientific-practical conference dedicated to the memory of V.M. Gorbatov. - Moscow, 2014. - № 1. - P. 17-18.

9. Rumyantseva G.N., Komissarova V.V., Semenova A.A. The use of herbal dietary fiber in cooked sausages // Meat industry, 2009. - № 11. - P. 37-39.

10. Lugasi A., Blázovics A., Hagymási K., Kocsis I., Kéry A. Antioxidant effect of squeezed juice from black radish (Raphanus sativus L. var niger) in alimentary hyperlipidaemia in rats / Phytother Res. 2005 Jul; 19(7): 587-91.

11. Sipos P., Hagymási K., Lugasi A., Fehér E., Blázovics A.Effects of black radish root (Raphanus sativus $L$. var niger) on the coIon mucosa in rats fed a fat rich diet / Phytother Res. 2002 Nov; 16(7): 677-9.

12. Sokolov A.A. Physico-chemical and biochemical basis of meat technology. - M.: Food processing industry, 1965. - P. 511. 13. Offer G., Trinick J. On the mechanism of water holding in meat: The swelling and shrinking of myofibrils // Meat Sci. 1983; 8(4):245-81. DOI: 10.1016/0309-1740(83)90013-X.

14. Puolanne E., Halonen M. Theoretical aspects of water-holding in meat // Meat Science.- Vol. 86, Issue 1, September 2010 , P. 151-165.

15. Vinauskienè R., Eisinaitè V., Jasutienè I., Leskauskaitè D. Composition and functional properties of meat products with a lyophilised vegetable additive // Food Chemistry and Technology. - Vol. 48. - № 1, 2014. - P. 78-86.

16. Patent WO 2005107500 A1.Vegetable fat replacement in meat products / Tornberg E., Sjöholm I. Published: Nov 17, 2005. 17. Abd-Elhak, Nasra A., Safaa E. Ali, Nahed L. Zaki. Innovative modification of traditional burger // Egypt. J. Agric. Res., 92(3), 2014. - P. 995-1008.

\section{AUTOR INFORMATION}

\section{Affiliation}

Bitueva Elvira Borisovna - doctor of technical sciences, professor, head of department, department of «Inorganic and analytical chemistry», East-Siberian state university of technology and management. 670013, Russian Federation, Ulan-Ude, Kluchevskaya st., 40в.

Tel.: 8-914-848-70-02

E-mail: bitueva_elv@mail.ru

Biltrikova Tatiana Vladimirovna - PhD student, department of "Inorganic and analytical chemistry», East Siberian state university of technology and management.

670013, Russian Federation, Ulan-Ude, Kluchevskaya st., 40в.

Tel.: 8-902-164-85-00

E-mail: biltrikova88@mail.ru

\section{Contribution}

Authors equally relevant to the writing of the manuscript, and equally responsible for plagiarism.

\section{Conflict of interest}

The authors declares no conflict of interest.

Received 19.10.2016 